\section{Genome Size and Seed Mass Analyses in Cicer arietinum (Chickpea) and Wild Cicer Species}

\author{
Sumin Kim, Mengqiao Han, and A. Lane Rayburn ${ }^{1}$ \\ Department of Crop Sciences, University of Illinois, 360 E R Madigan \\ Laboratory, 1201 West Gregory Drive, Urbana, IL 61801
}

Additional index words. 2C genome size, seed mass, Cicer arietinum, chickpea, wild Cicer

\begin{abstract}
The genome size of cultivated Cicer arietinum and 12 wild Cicer sp. including seven annual and five perennial species were analyzed using flow cytometry. A significant $2 \mathrm{C}$ genome size variation was observed among the $\mathrm{Cicer}$ sp. The $2 \mathrm{C}$ genome size ranged from $1.00 \mathrm{pg}$ in wild species, Cicer judaicum, to $1.76 \mathrm{pg}$ in cultivated species, $C$. arietinum. The wild perennial species all had a genome size of $\approx 1.6 \mathrm{pg}$. Most if not all of this genome size variation occurred among wild annual species. A significant positive correlation between $2 \mathrm{C}$ genome size and seed mass was observed among 12 wild $\mathrm{Cicer}$ sp. at $\alpha=0.05$. However, artificial selection appears to decrease nucleotype effects in cultivated $C$. arietinum, which resulted in no correlation between seed mass and genome size at $\alpha=0.05$.
\end{abstract}

The genus Cicer belongs to family Leguminoseae, subfamily Papilionaceae, tribe Cicereae, and is well known for the cultivated taxon, C. arietinum or chickpea. Cicer arietinum is the second most widely grown annual legume crop in the world, and has been mainly cultivated in the Indian subcontinent, West Asia, North Africa, America, and Australia (Singh et al., 2008). Besides the cultivated species, this genus is known to have 43 wild species including 8 annual and 35 perennial species (Singh et al., 2008, 2014; van der Maesen, 1987). The wild Cicer sp. are commonly found in West Asia and North Africa covering Turkey in the north to Ethiopia in the south, and Pakistan in the east to Morocco in the west (Singh et al., 2008). The wild annual species such as Cicer reticulatum, Cicer echinospermum, Cicer pinnatifidum, C. judaicum, Cicer bijugum, and Cicer cuneatum are being used in breeding programs to expand chickpea genetic diversity (Ladizinsky and Adler, 1976; Pundir and Mengesha, 1995; Pundir and van der Maesen, 1983; Singh and Ocampo, 1993; van der Maesen, 1980).

Knowledge of genetic relationships between the cultivated $C$. arietinum and its wild relatives plays an important role in assessing the origin of C. arietinum and in using its close relatives to facilitate the transfer of agonomically useful

Received for publication 25 Sept. 2015. Accepted for publication 3 Nov. 2015.

This material is based on work that is supported by the National Institute of Food and Agriculture, U.S. Department of Agriculture, Hatch project under ILLU-802-952.

We thank the USDA, ARS, National Genetic Resources Program-National Germplasm Resources Laboratory in Beltsville, MD for providing the seed material used for this study.

${ }^{1}$ Corresponding author. E-mail: arayburn@illinois. edu.

HortScience Vol. 50(12) December 2015
1972). The nucleotype effects can cause variation in phenotypic traits such as seed mass, and many previous studies have investigated the nucleotype effects on seed size and mass (Beaulieu et al., 2007; Bennett, 1987; Benor et al., 2010; Biradar et al., 1994; Chung et al., 1998; Knight and Ackerly, 2002). Most of the previous studies have indicated a positive relationship between genome size and seed mass within species and across species from the same genus and family (Benor et al., 2010; Biradar et al., 1994; Chung et al., 1998; Knight and Ackerly, 2002). However, in some cases, triangular (Bennett, 1987) and quadratic types of relationship between genome size and seed size (Beaulieu et al., 2007) were revealed in 1222 angiosperm species including, Alluium and Vicia, with species with large genomes tending to have large seed mass, whereas species with small genome sizes having either large or small seed mass. However, the correlation between genome size and seed mass may be disrupted by years of selective breeding/ artificial selection. According to previous studies (Doebley et al., 2006; Zhao et al., 2015), during the domestication of crops, the nucleotide diversity associated with the selected trait in crops is expected to be lower than that of the wild crops, due to strong selective cultivars over many years of generations. A similar result has been observed in cultivated C. arietinum. Seeds of $C$. arietinum can be phenotypically classified into two seed types: desi (small angular and dark colored) and kabuli (large owl-shaped cream colored) (Choudhary et al., 2012; van der Maesen, 1972). The desi types are mostly distributed in the Indian subcontinent, whereas the kabuli types are grown in the Mediterranean regions. Despite geographic divergence and phenotype differences, no significant difference in DNA content between the two seed types of C. arietinum were observed by Ohri and $\mathrm{Pal}$ (1991). However, until the issues of genome size estimates in C. arietinum are resolved, the reported nonassociation between genome size and seed type can be questioned. It is also important to examine the relationship between genome size and seed mass across wild Cicer $\mathrm{sp}$. for developing an understanding of nucleotype effects with regard to artificial and natural selection in Cicer sp.

In this study, we used flow cytometry to analyze nuclear DNA content of 13 Cicer sp. to provide valuable new genomic information for both genomic analysis and plant breeding strategies for cultivated plant improvement. Seed type and mass of Cicer sp. were investigated, and then the relationship between genome size and seed type/mass was examined within groups of cultivated C. arietinum and wild Cicer sp.

\section{Materials and Methods}

Such estimates are critical when correlating genome size variation with phenotypic variation.

The variation in genome size influences numerous cellular parameters such as chromosome size, nuclear volume, and cellular volume (Bennett, 1987; Grant, 1987), which has been called nucleotype effects (Bennett,
Plant material. Seeds of cultivated C. arietinum and 12 wild Cicer sp. (Table 2) were obtained from the National Plant Germplasm Resource Laboratory/USDA, ARS, National Genetic Resource Program (Beltsville, MD) (Table 2). The genotypes 
Table 1. Chromosome number, plant type, and genome size of Cicer sp. obtained in previous studies. The superscript lower case alphabet indicates the references.

\begin{tabular}{lclc}
\hline Species & Chromosome number & Plant type & 2C nuclear DNA content (pg) \\
\hline Cicer arietinum & $2 n=2 x=16^{\mathrm{z}}$ & Annual & $3.57^{\mathrm{x}}, 3.29^{\mathrm{w}}, 1.53^{\mathrm{v}}, 1.77^{\mathrm{u}}$ \\
Cicer bijugum & $2 n=2 x=16^{\mathrm{z}}$ & Annual & $2.54^{\mathrm{x}}$ \\
Cicer canariense & $2 n=2 x=16^{\mathrm{y}}$ & Perennial & - \\
Cicer chorassanicum & $2 n=2 x=16^{\mathrm{y}}$ & Annual & - \\
Cicer echinospermum & $2 n=2 x=16^{\mathrm{z}}$ & Annual & $2.7^{\mathrm{x}}$ and $2.61^{\mathrm{w}}$ \\
Cicer judaicum & $2 n=2 x=16^{\mathrm{z}}$ & Annual & $1.83^{\mathrm{x}}$ \\
Cicer multijugum & - & Perennial & - \\
Cicer nuristanicum & - & Perennial & - \\
Cicer pinnatifidum & $2 n=2 x=16^{\mathrm{z}}$ & Annual & - \\
Cicer pugens & $2 n=2 x=16^{\mathrm{y}}$ & Perennial & $2.65^{\mathrm{x}, \mathrm{w}}$ \\
Cicer reticulatum & $2 n=2 x=16^{\mathrm{z}}$ & Annual & - \\
Cicer songaricum & $2 n=2 x=16^{\mathrm{z}}$ & Perennial & - \\
Cicer yamashitae & $2 n=2 x=16^{\mathrm{y}}$ & Annual & -
\end{tabular}

${ }^{\mathrm{z}}$ Ladizinsky and Adler (1976).

${ }^{\mathrm{y}}$ Singh and Jauhar (2005).

${ }^{x}$ Ohri and Pal (1991).

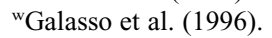

${ }^{v}$ Arunmuganthan and Earle (1991).

uRuperao et al. (2014).

$-=$ no information available. included 15 accessions for cultivated $C$. arietinum including PI 193782, PI 193767, PI 359817, PI 360659, PI 451607, PI 360662, PI 360663, PI 374079, PI 374090, PI 420908, PI 426190, PI 426551, PI 458870, W6 3125, and W6 32898 and 12 wild species consisting of 1 accession for each C. bijugum (PI 458552), Cicer canariense (PI 557453), Cicer chorassanicum (PI 458553), C. echinospermum (PI 599041), C. judaicum (PI 458559), Cicer multijugum (PI 599085), Cicer nuristanicum (PI 604497), Cicer pugens (W6 14191), and Cicer yamashitae (PI 540657) and 2 accessions for each C. pinnatifidum (PI 458555 and PI 458556), C. reticulatum (PI 599052 and 36, PI 599050), Cicer songaricum (PI 599053 and PI 599074). The seeds were grown in potting soil under $24 \mathrm{~h}$ light at $26^{\circ} \mathrm{C}$. About $2-12$ plants per Cicer accession were used for analysis of $2 \mathrm{C}$ genome size. Due to low germination rate, only

Table 2. Species accession, $2 \mathrm{C}$ genome size (mean $\pm \mathrm{SD}$ ), seed mass per 10 seeds (mean $\pm \mathrm{SD}$ ), seed type, and geographic origin of the Cicer accessions used in this study. Two different seed sizes were observed in desi (small and big) and kabuli (medium and large).

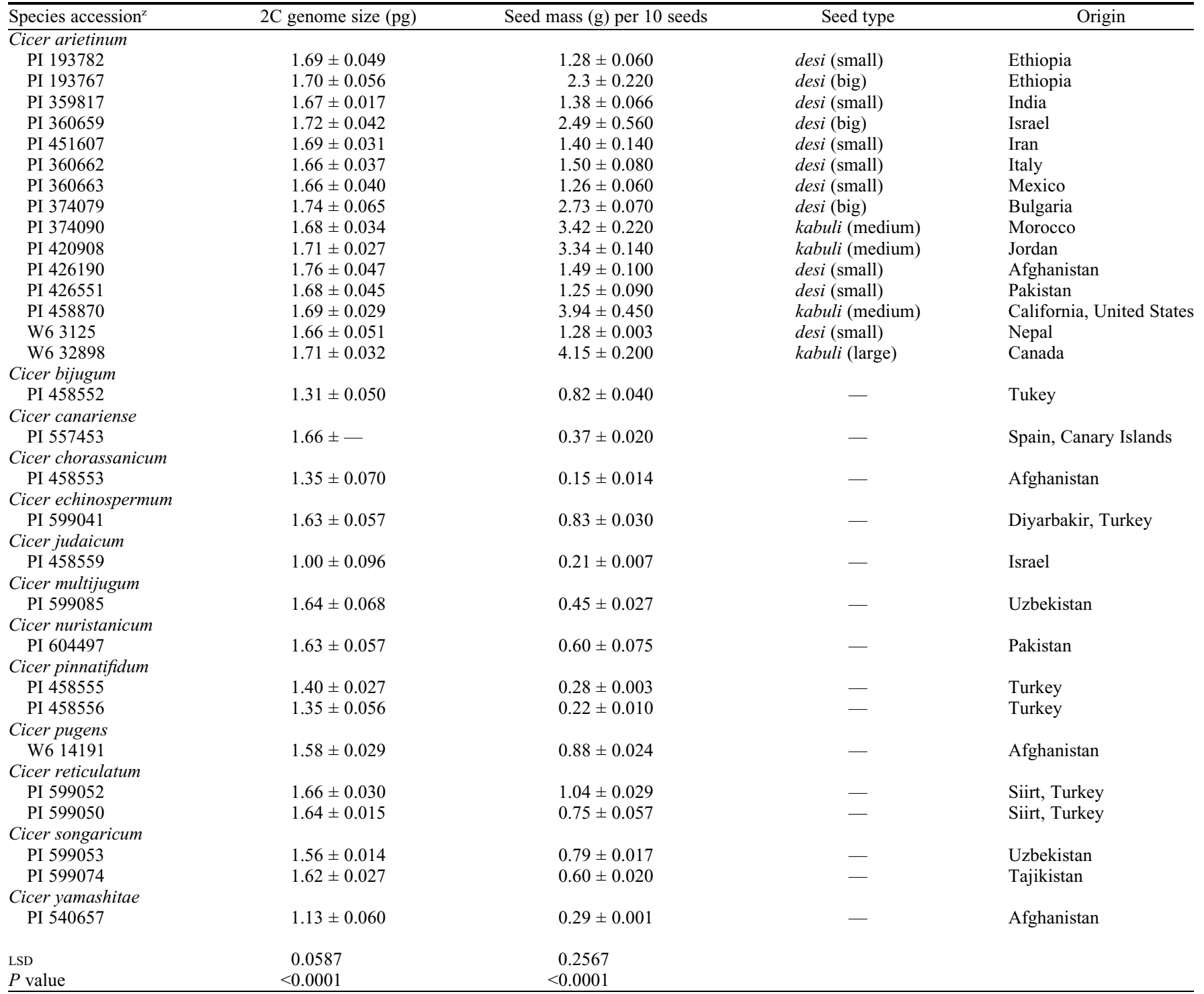

LSD $=$ least significant difference.

${ }^{\mathrm{z}}$ Accession obtained from the NPGRL/USDA, ARS, National Genetic Resource Program.

$-=$ no information available. 

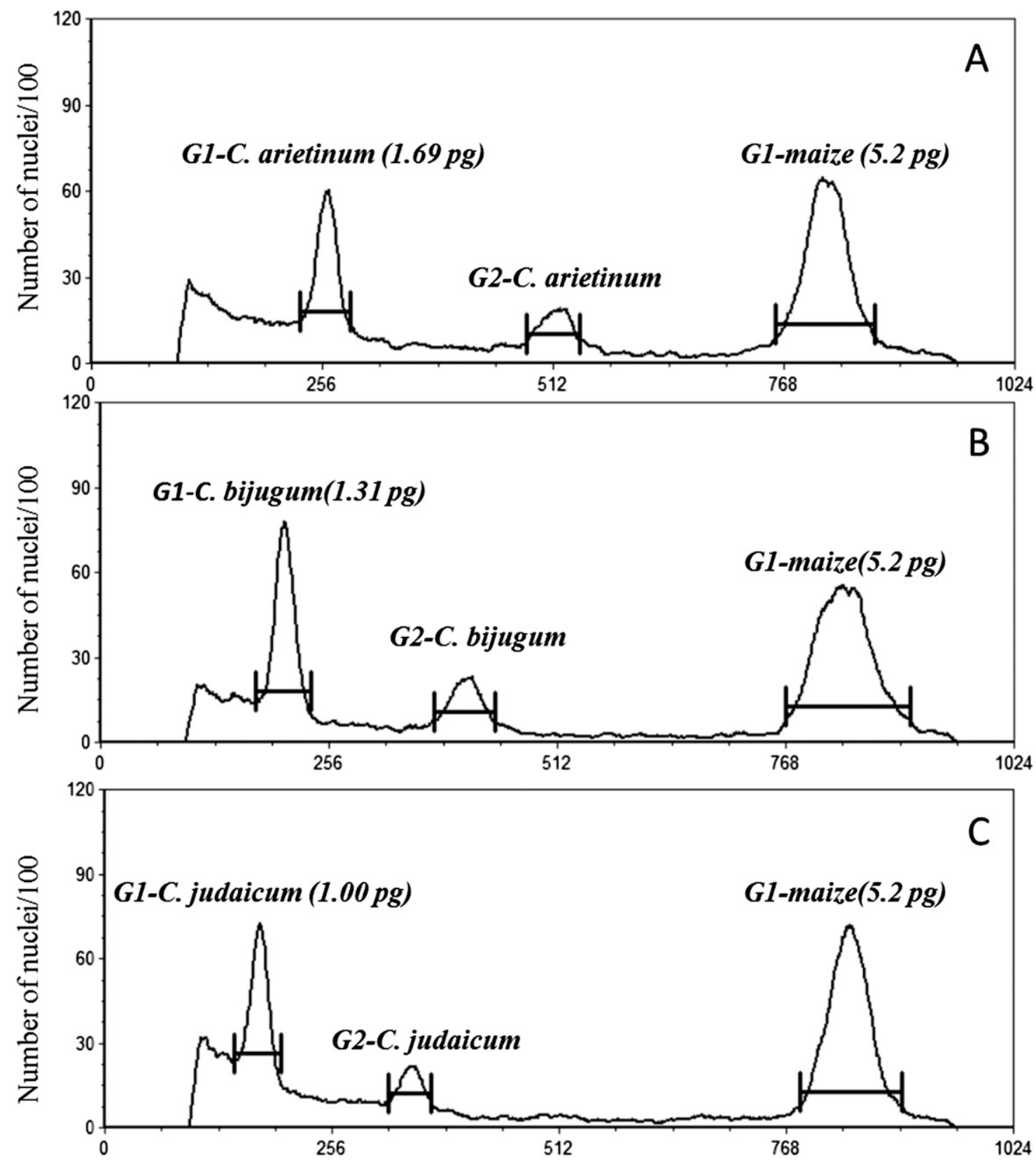

Fluorescence channel

Fig. 1. Flow histograms of Cicer sp. somatic nuclei stained with PI. The bar represents the nuclei used to calculate the mean fluorescence of each peak. (A) G1 somatic nuclei of Cicer arietinum. (B) G1 somatic nuclei of Cicer bijugum. (C) G1 somatic nuclei of Cicer judaicum.

one plant for C. canariense (PI 557453) was used for analysis of $2 \mathrm{C}$ genome size.

Analysis of genome size. To determine $2 \mathrm{C}$ genome size, flow cytometric analysis was performed using the protocol described by Kim et al. (2010). Fresh stem tissues $\left(\approx 5 \mathrm{~cm}^{2}\right.$ of each) from Cicer sp. and an internal standard were cochopped, and placed in $10 \mathrm{~mL}$ of extraction buffer and $200 \mu \mathrm{L}$ of $25 \%$ Triton $X$. The extraction buffer consisted of $13 \%$ hexylene glycol, $10 \mathrm{~mm}$ Tris$\mathrm{HCl}(\mathrm{pH} 8.0)$, and $10 \mathrm{~mm} \mathrm{MgCl}_{2}$. The use of the internal standard provides a relative measure of the $2 \mathrm{C}$ genome size of the sample. Maize was used as an internal standard because the $2 \mathrm{C}$ genome size of maize does not overlap with the targeted genome size of Cicer sp. The 2C genome size of maize (VT3 subpopulations) was calibrated at 5.15 pg using sorghum (Pioneer hybrid 84G62) with $1.74 \mathrm{pg} / 2 \mathrm{C}$ nuclei (Rayburn et al., 2009). For each sample, the tissue was homogenized using a tissue grinder for $10 \mathrm{~s}$ at $4500 g_{n}$, and the samples were filtered through a 50- $\mu \mathrm{m}$ filter (Partec, GmbH, Münster, Germany) into a test tube. After centrifuging for $15 \mathrm{~min}$ at $11,000 \mathrm{~g}_{\mathrm{n}}$ at $4{ }^{\circ} \mathrm{C}$, the supernatant was removed, and the nuclei were suspended in $300 \mu \mathrm{L}$ of PI stain $(3 \% \mathrm{w} / \mathrm{v}$ polyethylene glycol (PEG) $6000,5 \mu \mathrm{g} \cdot \mathrm{mL}^{-1}$ of PI, 180 units/ $\mathrm{mL}$ RNase, $0.1 \%$ Triton X-100 in $4 \mathrm{~mm}$ citrate buffer). The solution was transferred to a $1.5-\mathrm{mL}$ tube and incubated in a water bath for $20 \mathrm{~min}$ at $37^{\circ} \mathrm{C}$. PI salt stain $(3 \% \mathrm{w} / \mathrm{v}$ PEG
$6000,5 \mu \mathrm{g} \cdot \mathrm{mL}^{-1}$ of PI, and $0.1 \%$ Triton $\mathrm{X}-100$ in $400 \mathrm{~mm} \mathrm{NaCl}$ ) was added, and the tube was cooled to $4{ }^{\circ} \mathrm{C}$ for at least $1 \mathrm{~h}$.

A BD LSR II flow cytometer (BD Biosciences, San Jose, CA) was used to analyze the stained nuclei. The excitation wavelength was set at $488 \mathrm{~nm}$. The emission filter was a 695/40 nm-filter. At least 30,000 nuclei per sample were screened. The nuclei were gated on the basis of fluorescence integral vs. pulse width to exclude the doublets. The total $2 \mathrm{C}$ genome size reported in this study is the amount of nuclear DNA in somatic G1 nuclei of each plant.

Seed analysis. Seed photographs were taken using a color camera (DP22; Olympus, Shinjuku, Tokyo, Japan) through a zoom stereo microscope (S2-CTV; Olympus). The seed mass of three 
C. arietinum PI 360659

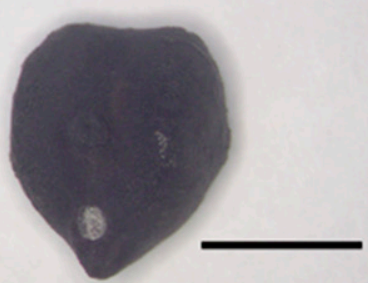

C. bijugum PI 458552

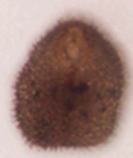

C. echinospermum PI 599041

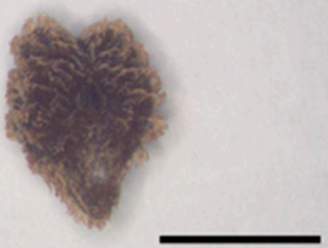

\section{C. nuristanicum PI 604497}

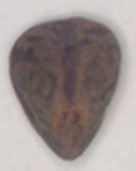

C. reticulatum PI 599050

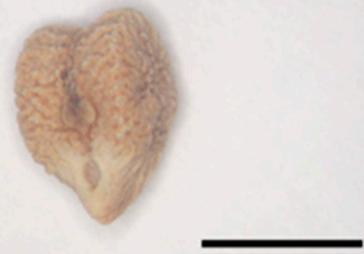

C. arietinum PI 360663

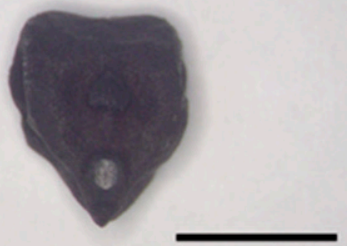

C. canariense PI 557453

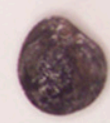

C. judaicum PI 458556

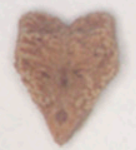

C. pinnatifidum PI 458559

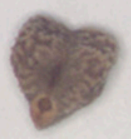

C. songaricum PI 599074

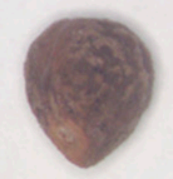

\section{C. arietinum PI 458870}

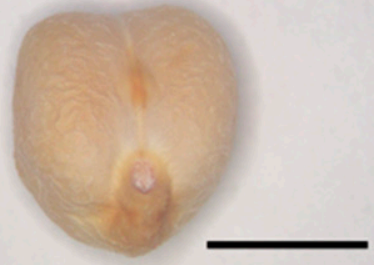

C. chorassanicum PI 458553

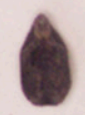

\section{C. multijugum PI 599085}

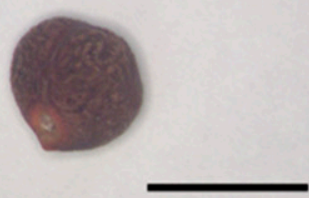

\section{C. pungens W 614191}

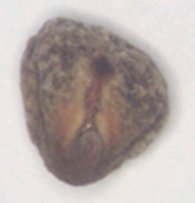

\section{C. yamashitae PI 540657}

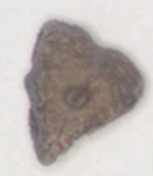

Fig. 2. The seed pictures of Cicer sp. Two different seed types are shown in Cicer arietinum: desi (PI 360659 and PI 360663) and kabuli (PI 458870). The size of bar is $1 \mathrm{~cm}$.

replicates of 10 seeds per Cicer accession were measured.

Statistical analysis. All statistical analyses were carried out using SAS 9.3 (SAS institute Inc., Cary, NY). General linear model analysis was conducted and Fisher's protected least significant difference test was run to determine the significant difference $(\alpha=0.05)$ among all Cicer accessions in 2C genome size and seed mass. The relationship between means of genome size and seed mass plotted on rawscaled axes (Niklas, 1994), which was carried out separately on accessions of the cultivated species (C. arietinum) and on accessions of wild Cicer sp. Bivariate trait relationships were analyzed by fitting a linear regression trend line using the least squares fit method (Herkimer, 1986). The linear relationship is expressed as $Y=\alpha+\beta X$, where $Y$ and $X$ stand for means of variables of seed mass and genome size, respectively, and $\alpha$ and $\beta$ represent the intercept on the $Y$ axis and the regression coefficient, respectively. F statistics were used for testing the null hypothesis that the regression coefficients are all equal to zero $(\alpha=0.05)$.

\section{Results and Discussion}

A significant difference in the average of $2 \mathrm{C}$ genome size was observed among Cicer $\mathrm{sp}$. ranging from 1.00 (C. judaicum) to $1.76 \mathrm{pg}$ (C. arietinum) $(P<0.0001)$ (Table 1; Fig. 1). Compared with perennial Cicer sp., a larger range of $2 \mathrm{C}$ genome size was observed among the annual Cicer sp. (Tables 1 and 2). Similar results have been observed by Ohri and $\mathrm{Pal}$ (1991) who reported a significant difference in $2 \mathrm{C}$ genome size among six annual Cicer sp. However, there are some discrepancies between the previous data and ours; in previous $2 \mathrm{C}$ genome size estimations (Table 1 ) (Galasso et al., 1996; Ohri and Pal, 1991), the results obtained were in most cases larger than observed in our study (Table 2). Some noticeable differences in the data on 


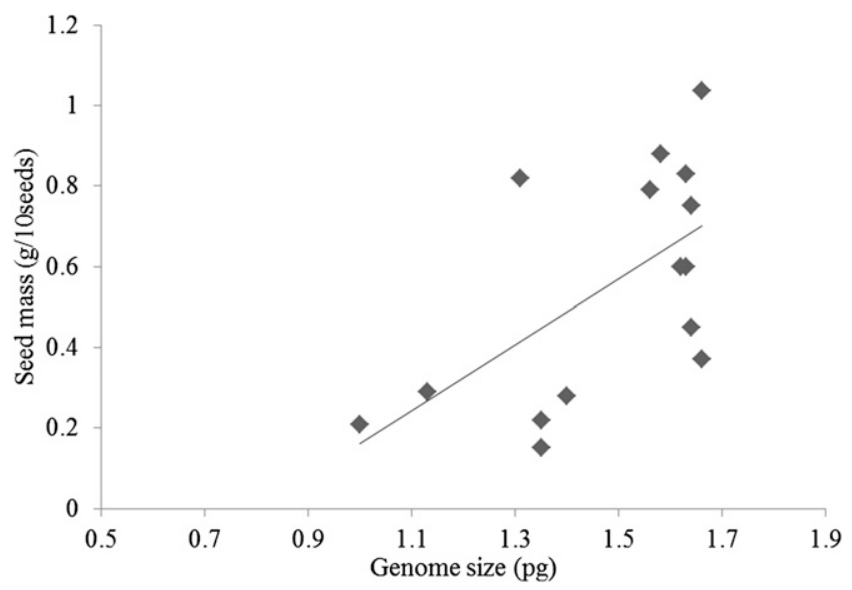

Fig. 3. The relationship between means of seed mass and means of genome size across 12 wild Cicer sp. (seed mass $=0.8157$, genome size $\left.=0.6533, R^{2}=0.3528, P=0.0196\right)$.

2C genome size were also observed in C. arietinum, C. bijugum, C. echinospermum, C. judacicum, C. pinnatifidum, and C. reticulatum. In these cases, previous estimations differed from ours by up to $80 \%$. Unlike the previous estimation, done by Ohri and $\mathrm{Pal}$ (1991) and Galasso et al. (1996), the 2C genome size of $C$. arietinum observed by Arumuganathan and Earle (1991) and Ruperao et al. (2014) is similar to our results (Table 2). In addition, the draft whole genome sequence of C. arietinum has been reported to be $\approx 738 \mathrm{Mb}$, which converts to a $2 \mathrm{C}$ genome size of $\approx 1.5 \mathrm{pg}$ (Varshney et al., 2013). Given these genome size results, a reassessment of the genome size for wild species was addressed.

The $2 \mathrm{C}$ genome size for $C$. arietinum, C. bijugum, C. echinospermum, C. judacicum, $C$. pinnatifidum, and $C$. reticulatum were observed around 1.7, 1.31, 1.63, 1.00, 1.38, and $1.65 \mathrm{pg}$, respectively (Table 2). In addition, the $2 \mathrm{C}$ genome sizes for other seven wild Cicer sp. including five perennial (C. canariense, C. multijugum, C. nuristanicum, C. pugens, and $C$. songaricum) and two annual species (C. echinospermum and C. yamashitae) were around 1.66, 1.64, 1.63, 1.58, 1.6, 1.63, and $1.13 \mathrm{pg}$, respectively (Table 2 ). Both in cultivated and wild Cicer sp., the genome size estimates were in agreement with lower genome sizes of $C$. arietinum. In addition, the chromosome size data of Ohri and Pal (1991) is more consistent with the genome sizes obtained in this study. Whether this is due to differences in technologies between flow cytometry and Feulgen DNA microdensitometry, internal standard species, technical issues, or other unknown factors could not be addressed. Given the three previous studies agree with the lower genome size of $C$. arietinum (Arumuganathan and Earle, 1991; Ruperao et al., 2014; Varshney et al., 2013), the association of seed characteristics with genome size was reevaluated.

Seed phenotypes such as size, color, shape, and seedcoating varied within $C$. arietinum and among Cicer sp. (Fig. 2). Within C. arietinum, the two distinctive seed types, such as desi and kabuli, were distributed widely over geographic regions (Table 2). Two different seed sizes were found in desi types (Fig. 2). The range of seed mass for the bigger size of the desi type was $2.3-2.5 \mathrm{~g}$, whereas the range of seed mass for the smaller size was $1.25-1.5 \mathrm{~g} / 10$ seeds (Table 2; Fig. 2). The seed size of the kabuli seed type also varied. According to Moreno and Cubero (1978) and Choudhary et al. (2012), the kabuli seeds used in this study can be classified into medium seeded (range 3.3-3.94 g/10 seeds) and large seeded ( $4.15 \mathrm{~g} / 10$ seeds) (Table 2). Seed phenotypes also varied among the wild species. Seed of wild perennial species are mostly round, triangular; shaped, and darker colored, but various seed sizes were found; higher seed phenotypic variations occurred within wild annual Cicer sp. (Fig. 2). Seed of C. reticulatum, which is well known as the wild progenitor of $C$. arietinum (Ahmad et al., 1987), has a mix of characteristics of desi (angular seed shape) and kabuli (cream color). Cicer bijugum has dark reddish colored hairy seedcoat, whereas $C$. echinospermum has a short yellowish colored hairy seedcoat (Fig. 3). Overall, the seed sizes of wild species were smaller than the two seed types of $C$. arietinum (Table 2), which reflects lower seed weights in wild species (Table 2).

The relationship between $2 \mathrm{C}$ genome size and seed mass was investigated within groups of the cultivated Cicer sp. (C. arietinum) and 12 wild Cicer sp. Because the cultivated species have been subjected to many years of artificial selection by plant breeders, the relationship between $2 \mathrm{C}$ genome size and seed mass of cultivated and wild Cicer sp. was considered separately. We found no correlation between $2 \mathrm{C}$ genome size and seed type within 13 lines of $C$. arietinum including the two seed types, desi and kabuli (seed mass = 11.436 , genome size $=17.187, R^{2}=0.107$, $P=0.233)$. The range of the $2 \mathrm{C}$ genome size within $C$. arietinum was between 1.66 and $1.76 \mathrm{pg}$ (Table 2 ). The seed types having both highest and lowest genome sizes were desi (Table 2). This result is also supported by Ohri and Pal (1991) who reported that no significant difference in DNA content was observed between desi and kabuli cultivars of $C$. arietinum, despite using the inflated genome size. However, a significant linear relationship was found between $2 \mathrm{C}$ genome size and seed mass among 12 wild Cicer $\mathrm{sp}$. (seed mass $=0.8157$, genome size $=0.6533$, $R^{2}=0.3528, P=0.0196$ ) (Fig. 3). For example, $C$. judaicum had the lowest genome size and also had lower seed mass. This strong positive relationship between genome size and seed mass in plants has also been observed in many previous studies (Bennett, 1972; Grime et al., 1997; Knight and Ackerly, 2002; Thompson, 1990). As genome size increases, the cell size within seed organs may get bigger, resulting in increase in seed mass (Beaulieu et al., 2008). Artificial selection appears to have disrupted the natural selection between genome size and seed mass in cultivated $C$. arietinum.

In conclusion, the $2 \mathrm{C}$ genome size estimations in this study confirm the previously reported findings, showing that the 1.5 (Arumuganathan and Earle, 1991) and $1.7 \mathrm{pg}$ (Ruperao et al., 2014) are the more accurate 2C genome sizes of $C$. arietinum, and that other estimated genome sizes of 3.29 and $3.57 \mathrm{pg}$ (Galasso et al.,1996; Ohri and Pal 1991) were likely an overestimation. In addition, the genome sizes for wild Cicer sp. estimated in this study were lower than the previous $2 \mathrm{C}$ genome sizes estimated in Ohri and Pal (1991) and Galasso et al. (1996). Significant differences in genome size were observed among 13 Cicer $\mathrm{sp}$. The $2 \mathrm{C}$ genome size ranged from $1.00 \mathrm{pg}$ in wild species, $C$. judaicum, to $1.76 \mathrm{pg}$ in cultivated species, C. arietinum. Compared with perennial Cicer sp., the $2 \mathrm{C}$ genome size more varied within annual Cicer sp.. Nucleotype effects appear to result in phenotypic variation across wild Cicer sp., but not across cultivated $C$. arietinum. No correlation between genome size and seed size was observed within C. arietinum, but a strong positive relationship between genome size and seed size was observed among 12 wild Cicer sp. By understanding the role of nucleotype and seed size, the potential exists to develop novel breeding schemes for $C$. arietinum improvement.

\section{Literature Cited}

Ahmad, F., A.E. Slinkard, and G.J. Scoles. 1987. Karyotypic analysis of annual Cicer L. species. Genet. Soc. Canada Bul. 18:130.

Arumuganathan, K. and E.D. Earle. 1991. Nuclear DNA content of some important plant species. Plant Mol. Biol. Rpt. 9:208-218.

Beaulieu, J.M., I.J. Leitch, S. Patel, A. Pendharkar, and C.A. Knight. 2008. Genome size is a strong predictor of cell size and stomatal density in angiosperms. New Phytol. 179:975-986.

Beaulieu, J.M., A.T. Moles, I.J. Leitch, M.D. Bennett, J.B. Dickie, and C.A. Knight. 2007. Correlated evolution of genome size and seed mass. New Phytol. 173:422-437.

Bennett, M.D. 1972. Nuclear DNA content and minimum generation time in herbaceous plants. Proc. R. Soc. Lond. B Biol. Sci. 181:109-135.

Bennett, M.D. 1987. Variation in genomic form in plants and its ecological implications. New Phytol. 106:177-200.

Benor, S., F.R. Blattner, S. Demissew, and K. Hammer. 2010. Collection and ethnobotanical investigation of Corchorus species in Ethiopia: Potential leafy vegetables for dry regions. Genet. Resources Crop Evol. 57:293-306. 
Biradar, D.P., D.G. Bullock, and A.L. Rayburn. 1994 Nuclear DNA amount, growth, and yield parameters in maize. Theor. Appl. Genet. 88:557-560.

Choudhary, S., K. Jagmeet, P. Chhuneja, J.S. Sandhu, S.J. Singh, and A. Sirari. 2012. Assessment of genetic diversity in kabuli chickpea (Cicer arietinum L.) genotypes in relation to seed size using SSR markers. J. Food Legume 26(1-2):96-99.

Chung, J., J.H. Lee, K. Arumuganathan, G.L. Graef, and J.E. Specht. 1998. Relationships between nuclear DNA content and seed and leaf size in soybean. Theor. Appl. Genet. 96:1064-1068.

Doebley, J.F., B.S. Gaut, and B.D. Smith. 2006. The molecular genetics of crop domestication. Cell 127:1309-1321.

Galasso, I., M. Frediani, M. Maggiani, R. Cremonini, and D. Pgnone. 1996. Chromatin characterization by banding techniques, in situ hybridization, and nuclear DNA content in Cicer L.(Leguminosae). Genome 39:258-265.

Grant, W.F. 1987. Genome differentiation in higher plants, p. 9-32. In: K.M. Urbanska (ed.). Differentiation patterns in higher plants. Academic Press, London, England.

Grime, J.P., K. Thompson, R. Hunt, J.G. Hodgson, J. H.C. Cornelissen, and I.H. Rorison. G.A.F. 1997. Integrated screening validates primary axes of specialization in plants. Oikos 79:259-281.

Herkimer, A.G. 1986. Understanding hospital financial management. 2nd ed. Aspen Publication, Rockville, MD. p. 133-136.

Kim, S., A.L. Rayburn, and D.K. Lee. 2010. Genome size and chromosome analyses in prairie cordgrass. Crop Sci. 50:2277-2282.

Knight, C.A. and D.D. Ackerly. 2002. Variation in nuclear DNA content across environmental gradients: A quantile regression analysis. Ecol. Lett. 5:66-76.

Ladizinsky, G. and A. Adler. 1976. Genetic relationships among the annual species of Cicer L. Theor. Appl. Genet. 48:197-203.
Moreno, M. and J.I. Cubero. 1978. Variation in Cicer arietinum. Euphytica 27:465-485.

Niklas, K.J. 1994. Plant allometry: The scaling of form and process. Chicago University Press, Chicago, IL.

Ohri, D. and M. Pal. 1991. The origin of chickpea (Cicer arietinum L.): Karyotype and nuclear DNA amount. Heredity 66:367-372.

Pundir, R.P.S. and M.H. Mengesha. 1995. Cross compatibility between chickpea and its wild relative, Cicer echinospermum Davis. Euphytica 83:241-245.

Pundir, R.P.S. and L.J.G. van der Maesen. 1983. Interspecific hybridization in Cicer. Int. Chickpea Nwsl. 8:4-5.

Rayburn, A.L., J. Crawford, C.M. Rayburn, and J.A. Juvik. 2009. Genome size in three Mischanthus species. Plant Mol. Biol. Rptr. 27:184-188.

Ruperao, R., C.K. Chan, S. Azam, M. Karafiátová, S. Hayashi, J. Cížková, R.K. Saxena, H. Simková, C. Song, J. Vrána, A. Chitikineni, P. Visendi, P.M. Gaur, T. Millán, K.B. Singh, B. Taran, J. Wang, J. Batley, J. Doležel, R.K. Varshney, and D. Edwards. 2014. A chromosomal genomics approach to assess and validate the desi and kabuli chickpea genome assemblies. J. Plant Biotechnol. 12:778-786.

Singh, M., I.S. Bisht, M. Dutta, K. Kumar, A.K. Basandrai, L. Kaur, A. Sirari, Z. Khan, A.H. Rizivi, A. Sarker, and K.C. Bansal. 2014. Characterization and evaluation of wild annual Cicer species for agro-morphological traits and major biotic stresses under Northwestern Indian conditions. Crop Sci. 54:229-239.

Singh, R.J. and P.P. Jauhar. 2005. Genetic resources, chromosome engineering, and crop improvement: Grain legumes, Vol. 1. Technology and Engineering CRC press, Boca Raton, FL.

Singh, K.B. and B. Ocampo. 1993. Interspecific hybridization in annual Cicer species. J. Genet. Breed. 47:199-204.
Singh, R., P. Sharma, R.K. Varshney, S.K. Sharma, and N.K. Singh. 2008. Chickpea improvement: Role of wild species and genetic markers. Biotechnol. Genet. Eng. Rev. 25:267-314.

Thompson, K. 1990. Genome size, seed size and germination temperature in herbaceous angiosperms. Evol. Trends Plants 4:113-116.

van der Maesen, L.J.G. 1972. Cicer L., a monograph of the genus: With special reference to the chickpea (Cicer arietinum L.), its ecology and cultivation. Mededelingen Landbouwhogeschool (Communications Agricultural University), Wageningen, Netherlands, Thesis p. 310-342.

van der Maesen, L.J.G. 1980. Growing wild chickpeas. Intl. Chickpea Nwsl. 2:3-4.

van der Maesen, L.J.G. 1987. Origin, history, and taxonomy of chickpea, p. 11-34. In: M.C. Saxena and K.B. Singh (eds.). The chickpea. $\mathrm{CAB}$ International Publications, Wallingford, UK.

Varshney, R.K., C. Song, R.K. Saxena, S. Azam, S. Yu, A.G. Sharpe, S. Cannon, J. Baek, B.D. Rosen, B. Tar'an, T. Millan, X. Zhang, L.D. Ramsay, A. Iwata, Y. Wang, W. Nelson, A.D. Farmer, P.M. Gaur, C. Soderlund, R.V. Penmetsa, C. Xu, A.K. Bharti, W. He, P. Winter, S. Zhao, J.K. Hane, N. Carrasquilla-Garcia, J.A. Condie, H.D. Upadhyaya, M.C. Luo, M. Thudi, C.L. Gowda, N.P. Singh, J. Lichtenzveig, K.K. Gali, J. Rubio, N. Nadarajan, J. Dolezel, K.C. Bansal, X. Xu, D. Edwards, G. Zhang, G. Kahl, J. Gil, K.B. Singh, S.K. Datta, S.A. Jackson, J. Wang, and D.R. Cook. 2013. Draft genome sequence of chickpea (Cicer arietinum) provides a resource for trait improvement. $\mathrm{Na}$ ture Biotechnol. 31:240-246.

Zhao, S., F. Zheng, W. He, H. Wu, S. Pan, and H.M. Lam. 2015. Impacts of nucleotide fixation during soybean domestication and improvement. BMC Plant Biol. 15:81. 